\title{
Principal-Principal Conflicts and Socioemotional Wealth in Family Firms
}

\author{
Jason See Toh Seong Kuan ${ }^{1}$, Chin Fei Goh ${ }^{1}$, Owee Kowang $\operatorname{Tan}^{1} \&$ Norliza Mohd Salleh ${ }^{1}$ \\ ${ }^{1}$ Faculty of Management, Universiti Teknologi Malaysia, Johor Bahru, Johor, Malaysia \\ Correspondence: Chin Fei Goh, Faculty of Management, Universiti Teknologi Malaysia, 81310 UTM, Johor \\ Bahru, Johor, Malaysia. E-mail: gcfei@utm.my
}

Received: August 5, 2017

Accepted: August 27, 2017

Online Published: September 5, 2017

doi:10.5539/ijef.v9n10p128

URL: https://doi.org/10.5539/ijef.v9n10p128

\begin{abstract}
Corporate governance is the concern of all the parties throughout the world regarding their viability in order to ensure the sustainability of the firm. As the family firms are listed in the public exchange, there are different kind of the investors in the corporation produce the resolution that are opposing to each other. Moreover, the large capital that is injected by the institutional investor complicates the role played in the corporation that shapes the culture and philanthropy. The phenomenon leads to the complex relationship in one corporation due to the different types of interest. Board composition and board independence are stretched by numerous scholars regarding the core importance in the corporation. Executive compensation is another area of corporate governance that is widely discussed by the scholars regarding the relationship with the long-term firm performance. Therefore, this review paper will focus on the application of the Principal-principal Conflicts theory and Socio-Emotional Wealth theory to narrate the whole scenario of the governance practice in the family firm. Throughout the paper, current rigorous practice of the family firms will be deeply investigated to cover the deep insights of the current phenomenon. The meticulous review of this paper is able to synthesize the significance of these theories towards the general governance setting in the family firms. Eventually, the working paradigm of the family firm can be clearly justified with the rationale that is justified. At the end of the review, the two main theories are concluded to be equally essential to illustrate the corporate governance practice in family firms across the globe.
\end{abstract}

Keywords: corporate governance, principal-principal conflicts, socio-emotional wealth, family firm

\section{Introduction}

Family firm has been in the industry for centuries and are mostly established with the core business stream that managed by the group of family members (Aguilera \& Crespi-Cladera, 2012). In term of the economic contribution, family firms leads the other firms in term of the profit generation (Harris \& Raviv, 1988). As the family firms usually dominates the market in the global, the role that exerted by the family firm is significantly important. Nonetheless, the monopoly of the management by the family members always being concerned by the industry practitioners. The external shareholders raise the anxiety of the return of investment as the firm owners do not create the desired result that is forecasted. Moreover, the firm owner will simply give the excuse of the miscellaneous factors and eventually lead to the unresolved crisis that ended with the bankruptcy of the entire firm. In the past decades, the corporate fraud and financial scandal that are reported have delivered a huge lost to the related shareholders, such as the Enron case and Worldcom problem (Thomas, 2002). Therefore, the code of governance is revised in time in order to enhance the existing practice to avoid the corporate fraud to happen again in the future.

\section{Literature Review}

\subsection{Background of Family Firm}

Among all of the pattern of the firm, family firm undoubtedly will be one of the most common firms in the world. The history of the family firm can be traced back to the ancient time as the family business is established with the specific core business stream. The firm will soon develop more channels by diversifying the business segments. The main role of the family firm will be mainly responsible to operate and oversee the daily business in the corporation. Nonetheless, the firm personnel do set the primary objective to safeguard the benefit and 
interest of the other shareholders. In order to play the better role, the firm owners will hold the highest share percentage in the corporation in order to gain the mandatory control rights. The rights grant them to have the authority to decide in the important matter that closely linked with their profit. Overall, most of the scholars agree that the $10 \%$ ownership by the owners will classify the firm as the family firms (Porta et al., 1999). The family firms will usually focus on their favorable business that having the distinctive competitive advantage. In the annual general meeting, the members will gather around to discuss the related matters and problems and then follow by the voting session.

\subsection{Institutional Setting of Family Firm}

Corporate governance remains as the main instrument of the corporate to function as a whole unit of the business entity as a norm (Globerman et al., 2011). The code of the governance will be clearly prescribed in the legal format that are required to be adhered by all the corporate members. Corporate governance functions as the ultimate code to ensure the protocol of the corporation stay on the correct track that guarantees the development of the corporation in the long term. In the typical corporation setting, the corporate governance of the company mainly focusses on the board matter and compensation issue (La Porta et al., 2000).

\subsubsection{Governance Mechanism}

In the general context, corporate governance structure can be divided into the internal governance mechanism and the external governance mechanism. Under internal governance setting, board committee functions as the important component to provide the necessary supervision to the corporation (Baysinger et al., 1991). The ratio of the dependent board members with independent board members is always considered as the hot debatable issue by the scholars. The kinship status between the board members and the firm owners create the discomfort and the anxiety to the shareholders. Meanwhile, compensation issue remains as one of the most challenging issue to be tackled as the management executive genuinely expect the high compensation after rendering the related service (Tosi \& Greckhamer, 2004). Moreover, the firm owners commonly treat the corporate resources as the personal asset, where withdrawing the decent amount of the compensation value is the common practice. For instance, the infamous case of the Enron is mainly due to the withdrawing of the high amount of the salary that eventually lead to the bankruptcy circumstances. Subsequently, the company CEO is convicted to the guilty of the mismanagement of the corporation.

External governance mechanism is coordinated by the corporate law that is required to be comprehended by all the related members (Djankov et al., 2008). In most of the countries, the public exchange will supervise the daily trading of the counter that accompanied by the coordination of the respective commission. Daily trading activity will be closely monitored by all the industry practitioners to ensure the legal and fairness of trading. Any insider trading or illegal practice will be heavily penalized by the commission. The enforcement is exerted with strong iron fist in order to set the leading role to all the public companies. The law also will be revised in time in order to avoid the compromising by the selected parties.

In general, there are six main components in the corporate governance that are mainly focused in the worldwide. In some of the countries, there is compulsory for the corporations to engage with the industry expert to deal with the governance issues in order to maintain thee good relationship with the investors. The effective system prevents the corporation falls into the fraud and mismanagement that eventually affects the operation of the corporation.

\section{Board matter}

Board committee functions as the independent committee to provide the supervision towards the management in order to ensure the corporate continue to operate and gaining the profit (Ozdemir \& Upneja, 2012). In general, the board members can be divided into the dependent directors and the independent directors. The ratio between the two groups always being debated by the scholars and revised from time being to suit the current development of the governance issue. As the board might be too broad to cover the governance, some of the countries will enforce the corporation to establish the specific board to cover the designated governance issue. For instance, remuneration committee is formed to handle the adjustment of the appropriate compensation to the management executives (Słomka-Gołębiowska \& Urbanek, 2016).

\section{Remuneration/Compensation}

Remuneration is always concerned by the external shareholders regarding the extraction of the corporate resources that leads to high expenses of the business operation (Raithatha \& Komera, 2016). In the recent years, cash compensation is no longer being popularized in the large firms due to the pressure that is exerted by the institutional investors. The investors are more willing the top management executives to receive the equity based 
compensation or stock options package. Thereafter, the firm owners will put more focus in the daily operation of the business and even possibly to gain more income from the profit sharing and bonus payout instead receiving the pure cash compensation.

\section{Managing director/CEO}

The top management is always alerted by the external parties regarding the ability to lead the corporation to the threshold level. In the family firm, CEO duality is the common phenomenon that is practiced by the firm owners, where they will hold the respective top position in the corporation to gain the necessary power control and authority (Ya'acob, 2016). Most of the firm owners will withdraw the decent salary from the service rendered. The situation get worsen when the firm owners set themselves with the high compensation. External shareholders concern about the high compensation that will distract the focus of the firm owner in the daily operation that eventually detrimental to the firm performance. In the recent years, the stock options is popularized in order to encourage the firm owner to spare more focus on gaining the revenue of the corporation that is accompanied by the respective reward either in the incentive reward, bonus payout or the company stock.

\section{Accounting/Auditing}

Accounting and auditing are the two areas that always being criticized by the external parties regarding the transparency level (Cho \& Wu, 2014). Moreover, some of the firm owners willing to manipulate the account and make the fake public announcement to cover the real scenario regarding the account status. Instead of the negative loss, the corporate will report the positive gain in order to gain the confidence from the shareholders. Eventually, the circumstances gets worsen and might lead to the bankruptcy of the corporation. Hence, the accounting matter receives greater attention in the recent years due to the accounting fraud that is reported (Fan \& Wong, 2005).

\section{Risk factor}

Risk in the business is always the great challenge that is encountered daily in every corporates especially in the financial companies that dealing with the high risk (Baek et al., 2004). The risk somehow is triggered by the competitors and the appropriate actions required to be taken to counteract the challenge. The risk committee will set the standard of the tolerance for the acceptable risk level. The adequate risk level will ensure the business is profitable and yet avoid the unnecessary lost due to the wrong decision that possibly made by the management.

\section{Annual General Meeting/Communication with shareholders}

Annual meeting is required to be conducted to protect the interest of the related stakeholders, naming the majority shareholders and the minority shareholders. The communication among all the corporate members is treated with the highest attention to ensure the harmonious business environment is maintained. All the shareholders should be able to provide their proposed resolution to the board and the voting will be performed to select the best option. Meanwhile, the attendance of the directors is compulsory and will be recorded for the further reference of the re-nomination. Moreover, the investor relation department is required to be established to take care the consideration of the shareholders. The mandatory disclosure is released periodically for the informative reference of the investors.

\subsubsection{Governance Models}

Basically, there will be three most common forms of the governance mechanism that practiced by the corporate firms in the worldwide. Basically, the institutional setting divides into the two main branches, which are the types of Anglo American and Continental Europe. In the Asia, most of the companies will have the own set of the Asian governance by adapting the main concept of Anglo American setting with the minor adjustment. In term of the liability, most of the companies will not bear the responsibility of the debt due to the private limited status. All the governance models have the common components that function as the backbone of the corporation (Rajablu, 2016). Nonetheless, each of the governance model has its own distinctive advantages and disadvantage that required to be greatly taken care without compromising the negative impact that delivered to the stakeholders.

\section{Anglo American governance model}

Anglo American system emphasize the power of the board to provide the supervision towards the management of the corporation. The single tier of the governance model that are practiced will genuinely allow the practice of CEO duality in the corporation. Hence, most of the firm owners will hold the position of the top management in order to gain the maximum power control. Annual corporate meeting that is held will collect the resolution that proposed by the different kind of the shareholders. In order to enhance the strong bond between the corporate 
with the shareholders, the constructive ideas of the shareholders will be taken with the sincere consideration. Therefore, Anglo American model will somehow prioritize the board and the shareholders more than the management executives. The model also provides more flexibility towards the firm in term of the management of the company.

\section{Continental Europe governance model}

In the Continental Europe model, there will be the common two tiers model that are practiced by the European corporate firms. By referring to the respective model, it is widely being practiced in the countries of Germany and Italy. The two level models will be the board committee and the supervisory auxiliary level. While the board committee functions to supervise towards the management, the supervisory model functions to supervise the board committee to avoid the biasness of the board's operation. The two tiers of the supervision also able to prevent any possibility of the corporate fraud. Therefore, Continental Europe model is considered as the most secured model comparing to the rest of the practices.

\section{Asian corporate governance model}

In the Asian's case, most of the corporations receive the funding from the government and state for the main business operation. The standard of the Asian case is widely influenced by the national government policy and the cash reserve. Japan is one of the Asian's countries that practices the strong Asian corporate governance model due the strong involvement of the government in the investment of the corporation. The risk factor and the profit consideration are aimed to get balanced among all the stakeholders. The scenario gets more attention due to the requirement that are set by the government as the fund is commonly sourced from the public fund that is required to respond to the respective allegation. The strong influence by the large shareholder is indirectly affecting the interest of the retail traders due to the small voting rights.

\subsection{Related Theoretical Foundation}

In the research of the issue of family firm, Socio-Emotional Wealth theory and the Principal-principal conflict theory undoubtedly will be the best theories to illustrate the phenomenon in the family firm (Gómez-Mejía et al., 2007). Both of the theories put the core attention towards the accurate phenomenon and the scenario that is happening in the family corporations. The cause and the impact that are derived by the family corporation can be clearly understood by studying these theories in details.

\subsubsection{Principal-Principal Conflicts (PP Conflicts)}

Principal-principal conflict was introduced in the late nineties in order to narrate the common argument between the major shareholders and the minority shareholders (Peng et al., 2008). PP conflicts focusses more into the argument between the external parties and the internal management. Nonetheless, the agency cost is incurred due to the ineffectiveness of the management that is caused by the agency conflicts. Since the firms tend to set the policy that against the main interest of the rest of the shareholders, the group will fight against the decision maker in order to claim the deemed benefit (Renders \& Gaeremynck, 2012). Agency cost and negative loss are incurred to the corporation due to the conflict that is happened between the members (Fama \& Jensen, 1983). Tunneling occurs when the firm owners reluctant to disclose the decent information to the public in order to protect private benefit (de Silanes et al., 2000). The entrenchment effect is unintentionally created due to the different working philosophy that is practiced. As the voting percentage is limited to the minority shareholders, the coalition will be formed within the group in order to stand against the major power that held by the firm owner. The ally will enhance the interest of the group of the minority shareholders when the voting rights increase accordingly.

Overall, PP Conflicts theory is extensively applied in the study of the corporate firms either in the formal institutions or informal institutions (Peng et al., 2008). Due to the existence of the investment by the shareholders, the conflict is ignited among the related corporate members that affects the harmonious business environment. In the long run of the business, the operation and the reputation of the corporation will receive severe negative impact.

\section{Formal Institution}

Formal institution usually consists of the established corporate that is listed in the public exchange for the purpose of gathering the large capital fund. In the formal institution, the size of the corporate will be clearly written and prescribed by the corporate law. PP conflict usually exists between the top management and the institutional shareholders due to the phenomenon of multiple large shareholders (Jiang \& Peng, 2011). The large shareholders have the high standard to achieve and expecting the firm comprehend their expectation to able to reach to the desired firm performance. For instance, the institutional investors will prefer the management 
executives to concentrate more into generating the profit instead of withdrawing the high compensation value. Therefore, the different kind of working standard eventually triggers the conflict among the shareholders.

\section{Informal Institution}

In general, informal institution is usually consists of the small firms and the family firms. After several years of the business operation, most of the informal institutions will upgrade the informal setting to the formal institution via listing in the public exchange (Sauerwald \& Peng, 2013). Informal institution will commonly be the firms that are not tightly governed with the formal written rule. The relationship among all the members will be close and attached by the close personal bond. Some of the corporations will receive the capital injection by the private investors. The investors usually also have the strong personal relationship with the firm owners. Nonetheless, the group of the investors might be having their own standard and expecting the corporation to act according to their requests (Ljungqvist et al., 2007). Hence, the conflict is occurred between the principals in the informal institution as well that possibly affecting the daily operation of the corporation.

\subsubsection{Socio-Emotional Wealth (SEW)}

Institutional setting of family firm is very crucial in the typical setting of the family firm. The necessary protocol is required to be prescribed clearly to handle the matter that possibly raised by all the related stakeholders. As SEW theory illustrates the paths of emotion, the psychological part of the decision will be involved in the decisive issues of the decision making process. The firm owner will act according to their best interest instead of the major will of the shareholder in the corporation (Gómez-Mejía et al., 2007). Despite that the philosophy abiding the corporate law, the ethical part of the protocol is challenged and get criticized (Brander and Spencer, 1989). The personal interest of the firm owner will be allocated with the utmost consideration in order to maximize the benefit that being prioritized. The firm owner will ensure holding the veto decision making power in order to ensure the handling of the ultimate decision making process. The stronghold of the power by the family members will eventually affect the transparency level of the corporation to the public. Public reputation of the corporation is important for a corporation to build the positive image for the publicity purpose.

By following the theory is prescribed by Berrone et al. (2012), SEW identifies the five main components that are described as below:

\section{Family Control and Influence}

The family control in the family firm is always relative strong comparing to the other form of the business pattern (Kuo \& Hung, 2012). The control remains significantly important for the firm owners to safeguard their wealth and interest regardless of the ownership status. The firm owners simply gain larger decision making power in the corporation that will provide them the sufficient voting power and ownership rights. The firm control also important to avoid the hostile takeover activity by the external party that always seek for the golden opportunity.

\section{Family Identification}

In the family firm, the identity of the family firm remains the greatest asset to be perceived by the firm owners. Moreover, the family identification is able to attract the large fund of the external investors. The group of the institutional investors will just look into the high-profile entrepreneur that able to deliver the high profit towards them. Firm owners will just simply aspire to set up the strong brand identity to expand the business in the near future. The positive attribute is built to shape the positive reputation to the public. The positive image also can stimulate the expansion of the revenue of the business tremendously.

\section{Binding Social Ties}

The social connection that is built will be crucial for the firm owners to gain the major control in the corporation, especially in the annual general meeting (Gomez-Mejia et al., 2001). The binding will usually link up with the members that have the kinship connection. The group of the people will hold the position in the top management and channeling the assistance to each other in order to smoothen the workflow. Moreover, the firm owner will assign the related members in the various types of department that providing the coordination among each other.

\section{Emotional Attachment}

As the nature instinct of the human being, the psychological aspect of the human remains as the significant factor that influences the action of the peoples (Carstensen et al., 2000). The decisions that are made are usually mixed with much emotional factor that will bring the significant impact to the ultimate output. The elements that are considered vary according to the people and yet to be receive the major consent by the rest of the stakeholders. The complicated issue leads to the undesirable phenomenon that is encountered in the corporation. 


\section{Renewal of the family bond through succession}

The common tradition of the family firm will be the transition of the business into the further generation so that the wealth of the family can be preserved. Most of the current firm owners will set the will and ensure the transition is not affected. Moreover, the firm owner will have the personal training to their successor before they step down from the position. Despite retirement, they will still play the nominal role in the mentorship or advisory job in order to ensure the philosophy of the corporate is not diverted (Dieleman et al., 2013).

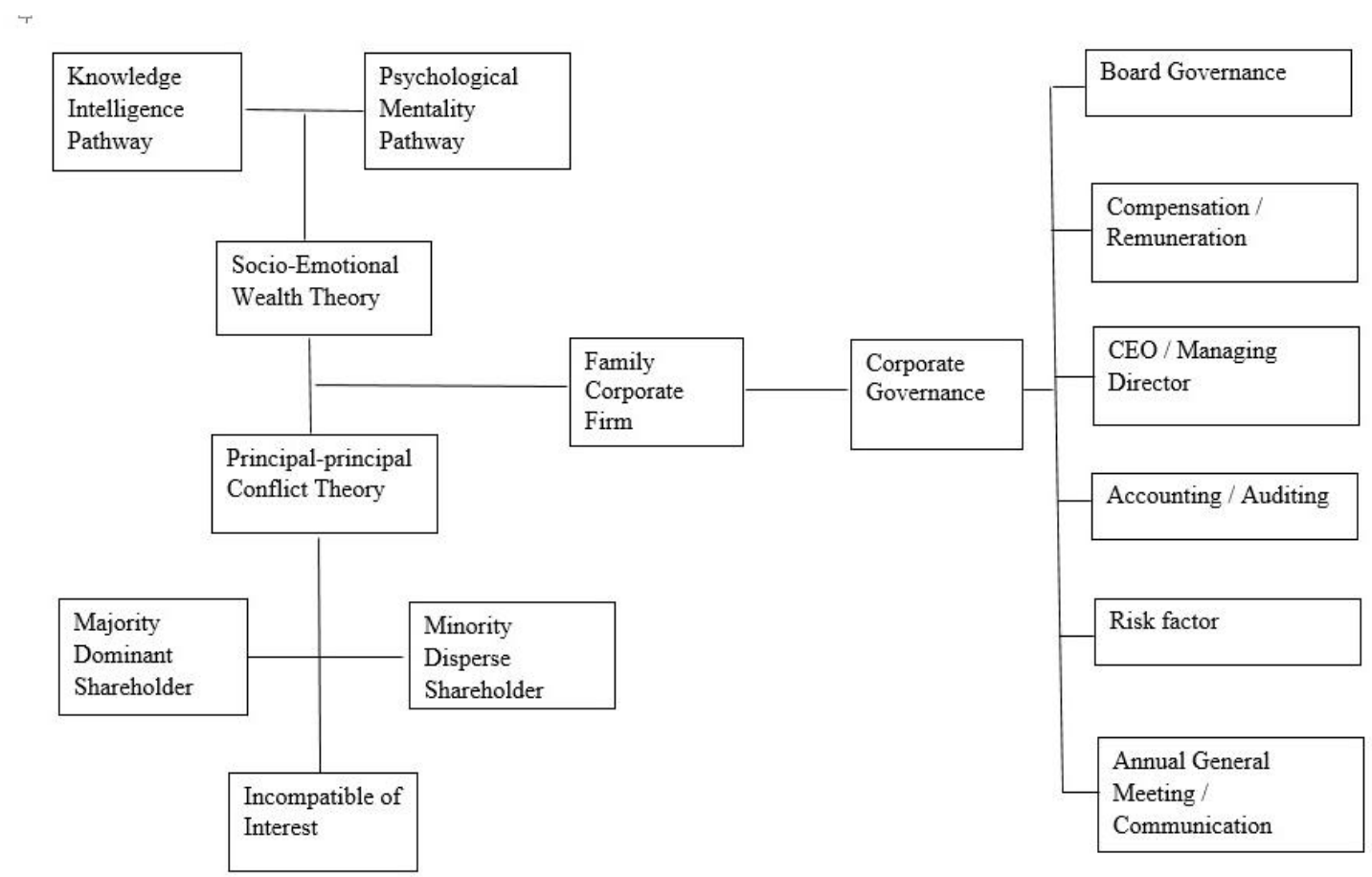

Figure 1. Conceptual research diagram

\section{Conclusion}

Throughout the entire research, the study aims to investigate the routine governance protocol and the corporate philanthropy that are practiced in the corporate firms. Based on the review, the new paradigm can be set to provide the new insights regarding the latest development of the practicable governance. As the global economy continue to rise, the necessary governance is required to be enhanced to ensure the sustainability of the firm. There has been a lot of the corporate fraud that happen in the past decades that eventually delivering the extreme negative impact to the stakeholders. Besides the unnecessary financial lost that is received, reputation of the related parties will be deeply affected in the future. Hence, an established corporation is strongly advised to have the systematic governance practice that able to sustain the business in order to generate the desired profit. Then, the institutional investors will be more willing to inject the large capital into these companies in the long term (Song et al., 2016).

\subsection{Theoretical and Practical Contribution}

This paper focuses on providing the substantial contribution in the governance practice that is implemented in the family firm. In the recent years, family control grows significantly due to the firm owners take more aggressive role to safeguard their personal interest. Compensation package is tailored made for the top management by considering the internal and external factors. Board matter in the corporation is allocated with the decent attention that is able to improve the supervision towards the corporation management. By applying the mixture of Principal-principal Conflicts and Socio-Emotional Wealth theory, the research is able to explore the impact that is derived by the family firm towards the public investors as well as institutional investors. The firm owners able to study the specific characteristic and influence that are exhibited in the corporation. Subsequently, the tactical corporate strategy can be formulated to tackle the respective problem that is encountered.

\subsection{Economic Impact}

Moreover, the research aims to deliver the economic impact value by providing contribution to enhance the corporate performance that is desired. By implementing the appropriate corporate policy, revenue of the 
corporation can grow substantially. The significant output can be observed via the return of investment of the shareholders that able to receive in each of the quarters. The lucrative return of the investment can ensure the loyalty and sustainability of the capital investment from the shareholders. The liquidity of the capital is very important for the corporation to focus in the long term of the corporate development and profitable projects.

\subsection{Future Research}

The future research will focus on the data finding and the data analysis after collecting the secondary data from the panel data portal. Further, the analysis should include more recent data to provide the more significance of the entire research. Besides that, the specific characteristic of the governance variables can be clearly investigated depending to the research parameters in order to provide better understanding towards the corporate governance in the family firm.

\section{References}

Aguilera, R. V., \& Crespi-Cladera, R. (2012). Firm family firms: Current debates of corporate governance in family firms. Journal of Family Business Strategy, 3(2), 66-69. http://dx.doi.org/10.1016/j.jfbs.2012.03.006

Baek, J. S., Kang, J. K., \& Suh Park, K. (2004). Corporate governance and firm value: Evidence from the Korean financial crisis. Journal of Financial Economics, 71(2), 265-313. http://dx.doi.org/10.1016/S0304-405X(03)00167-3

Baysinger, B. D., Kosnik, R. D., \& Turk, T. A. (1991). Effects of Board and Ownership Structure on Corporate R\&D Strategy. The Academy of Management Journal, 34(1), 205-214. http://dx.doi.org/10.2307/256308

Berrone, P., Cruz, C., \& Gomez-Mejia, L. R. (2012). Socioemotional wealth in family firms theoretical dimensions, assessment approaches, and agenda for future research. Family Business Review, 25(3), 258-279. https://doi.org/10.1177/0894486511435355

Brander, J. A., \& Spencer, B. J. (1989). Moral Hazard and Limited Liability: Implications for the Theory of the Firm. International Economic Review, 30(4), 833-849. http://dx.doi.org/10.2307/2526754

Carstensen, L. L., Pasupathi, M., Mayr, U., \& Nesselroade, J. R. (2000). Emotional experience in everyday life across the adult life span. Journal of Personality and Social Psychology, 79(4), 644. http://dx.doi.org/10.1037/0022-3514.79.4.644

Cho, C. C., \& Wu, C. H. (2014). Role of auditor in agency conflict and corporate governance: Empirical analyses of Taiwanese firms. Chinese Management Studies, 8(3), 333-353. http://dx.doi.org/10.1108/CMS-09-2012-0126

De Silanes, F. L., Johnson, S., La Porta, R., \& Shleifer, A. (2000). Tunneling. Paper presented at the American Economic Review Papers and Proceedings.

Dieleman, M., Shim, J., \& Ibrahim, M. (2013). Asian Family Firms: Success and Succession.

Djankov, S., La Porta, R., Lopez-de-Silanes, F., \& Shleifer, A. (2008). The law and economics of self-dealing. Journal of Financial Economics, 88(3), 430-465. http://dx.doi.org/10.1016/j.jfineco.2007.02.007

Fama, E. F., \& Jensen, M. C. (1983). Agency problems and residual claims. Journal of Law and Economics, 327-349. http://dx.doi.org/10.1086/467038

Fan, J. P., and Wong, T. J. (2005). Do external auditors perform a corporate governance role in emerging markets? Evidence from East Asia. Journal of Accounting Research, 43(1), 35-72. http://dx.doi.org/10.1111/j.1475-679x.2004.00162.x

Globerman, S., Peng, M. W., \& Shapiro, D. M. (2011). Corporate governance and Asian companies. Asia Pacific Journal of Management, 28(1), 1-14. http://dx.doi.org/10.1007/s10490-010-9240-6

Gómez-Mejía, L. R., Haynes, K. T., Núñez-Nickel, M., Jacobson, K. J., \& Moyano-Fuentes, J. (2007). Socioemotional wealth and business risks in family-controlled firms: Evidence from Spanish olive oil mills. Administrative Science Quarterly, 52(1), 106-137. http://dx.doi.org/10.2189/asqu.52.1.106

Gomez-Mejia, L. R., Nu, xf, ez-Nickel, M., \& Gutierrez, I. (2001). The Role of Family Ties in Agency Contracts. The Academy of Management Journal, 44(1), 81-95. http://dx.doi.org/10.2307/3069338

Harris, M., \& Raviv, A. (1988). Corporate governance. Journal of Financial Economics, 20, 203-235. http://dx.doi.org/10.1016/0304-405X(88)90045-1

Jiang, Y., \& Peng, M. (2011). Principal-principal conflicts during crisis. Asia Pacific Journal of Management, 28(4), 683-695. http://dx.doi.org/10.1007/s10490-009-9186-8 
Kuo, Y. P., \& Hung, J. H. (2012). Family Control and Investment-Cash Flow Sensitivity: Moderating Effects of Excess Control Rights and Board Independence. Corporate Governance: An International Review, 20(3), 253-266. http://dx.doi.org/10.1111/j.1467-8683.2011.00899.x

La Porta, R., Lopez-de-Silanes, F., Shleifer, A., \& Vishny, R. (2000). Investor protection and corporate $\begin{array}{lllll}\text { governance. Journal of } & \text { Financial } & \text { Economics, } & 58(1-2), & 3-27 .\end{array}$ http://dx.doi.org/10.1016/S0304-405X(00)00065-9

Ljungqvist, A., Marston, F., Starks, L. T., Wei, K. D., \& Yan, H. (2007). Conflicts of interest in sell-side research and the moderating role of institutional investors. Journal of Financial Economics, 85(2), 420-456. http://dx.doi.org/10.1016/j.jfineco.2005.12.004

Ozdemir, O., \& Upneja, A. (2012). Board structure and CEO compensation: Evidence from U.S. lodging industry. International Journal of Hospitality Management, 31(3), 856-863. http://dx.doi.org/10.1016/j.ijhm.2011.10.004

Peng, M. W., Wang, D. Y. L., \& Jiang, Y. (2008). An institution-based view of international business strategy: A focus on emerging economies. Journal of International Business Studies, 39(5), 920-936. http://dx.doi.org/10.1057/palgrave.jibs.8400377

Porta, R., Lopez-de-Silanes, F., \& Shleifer, A. (1999). Corporate ownership around the world. The Journal of Finance, 54(2), 471-517. http://dx.doi.org/10.1111/0022-1082.00115

Raithatha, M., \& Komera, S. (2016). Executive compensation and firm performance: Evidence from Indian firms. Iimb Management Review, 28(3), 160-169. https://doi.org/10.1016/j.iimb.2016.07.002

Rajablu, M. (2016). Corporate governance: A conscious approach for Asia and emerging economies. International Journal of Law and Management, 58(3), 317-336. http://dx.doi.org/10.1108/IJLMA-04-2015-0017

Renders, A., \& Gaeremynck, A. (2012). Corporate Governance, Principal-Principal Agency Conflicts, and Firm Value in European Listed Companies. Corporate Governance: An International Review, 20(2), 125-143. http://dx.doi.org/10.1111/j.1467-8683.2011.00900.x

Sauerwald, S., \& Peng, M. W. (2013). Informal institutions, shareholder coalitions, and principal-principal $\begin{array}{lllll}\text { conflicts. Asia Pacific Journal of Management, } & \text { 30(3), }\end{array}$ http://dx.doi.org/10.1007/s10490-012-9312-x

Słomka-Gołębiowska, A., \& Urbanek, P. (2016). Corporate boards, large blockholders and executive compensation in banks: Evidence from Poland. Emerging Markets Review, 28, 203-220. https://doi.org/10.1016/j.ememar.2016.08.001

Song, Y., Gianiodis, P. T., \& Li, Y. (2016). Institutional Ownership and Corporate Philanthropic Giving in an Emerging Economy. Management and Organization Review, 12(2), 357-385. http://dx.doi.org/10.1017/mor.2015.33

Thomas, C. W. (2002). The rise and fall of Enron. Journal of Accountancy, 193(4), 41.

Tosi, H. L., \& Greckhamer, T. (2004). Culture and CEO Compensation. Organization Science, 15(6), 657-670. http://dx.doi.org/10.1287/orsc.1040.0099

Ya'acob, N. S. (2016). CEO Duality and Compensation in the Market for Corporate Control: Evidence from $\begin{array}{lllll}\text { Malaysia. Procedia } & \text { Economics }\end{array}$ http://dx.doi.org/10.1016/S2212-5671(16)00039-3

\section{Copyrights}

Copyright for this article is retained by the author(s), with first publication rights granted to the journal.

This is an open-access article distributed under the terms and conditions of the Creative Commons Attribution license (http://creativecommons.org/licenses/by/4.0/). 